\title{
SARS coronavirus infection: pathology and pathogenesis of an emerging virus disease
}

\author{
Sherif R. Zaki and Cynthia S. Goldsmith \\ Infectious Disease Pathology Activity, Division of Viral and Rickettsial Diseases, National \\ Center for Infectious Diseases, Centers for Disease Control and Prevention (CDC), Atlanta, \\ GA 30333, USA
}

\section{Introduction}

Severe acute respiratory syndrome (SARS) was first recognized during a global outbreak of severe pneumonia that first occurred in late 2002 in Guangdong Province, China, and then erupted in February 2003 with cases in more than two dozen countries in Asia, Europe, North America, and South America. The disease causes an influenza-like illness with fever, cough, dyspnea, and headache, and in severe cases, it can cause human death. Person-to-person transmission, combined with international travel of infected persons, accelerated the worldwide spread of the illness, and by the time the outbreak was contained, 8,098 probable cases resulting in 774 deaths were reported [1-4]. During the outbreak, a global network of 11 laboratories was established by the World Health Organization (WHO) to identify the causal agent. Early in the investigation, the clinical, pathologic, and laboratory studies focused on previously known agents of respiratory illness. Subsequently, however, a previously unknown virus was isolated from the oropharynx of a SARS patient and identified by ultrastructural characteristics as belonging to the family Coronaviridae [5-7]. These findings shifted the focus of the investigation toward verification of the role played by this newly recognized coronavirus. A vast array of laboratory approaches was utilized in this investigation, including pathologic, serologic, and molecular assays [6-10]. Within weeks, infection of non-human primates was achieved, thus establishing an animal model for SARS coronavirus (SARS-CoV) [11].

This chapter presents the morphologic characteristics of SARS-CoV grown in tissue culture and the histopathologic changes, electron microscopic findings, and cellular localization of the virus in tissues from human patients and experimentally infected animals. In addition, the pathophysiology of this newly emergent virus will be discussed. 


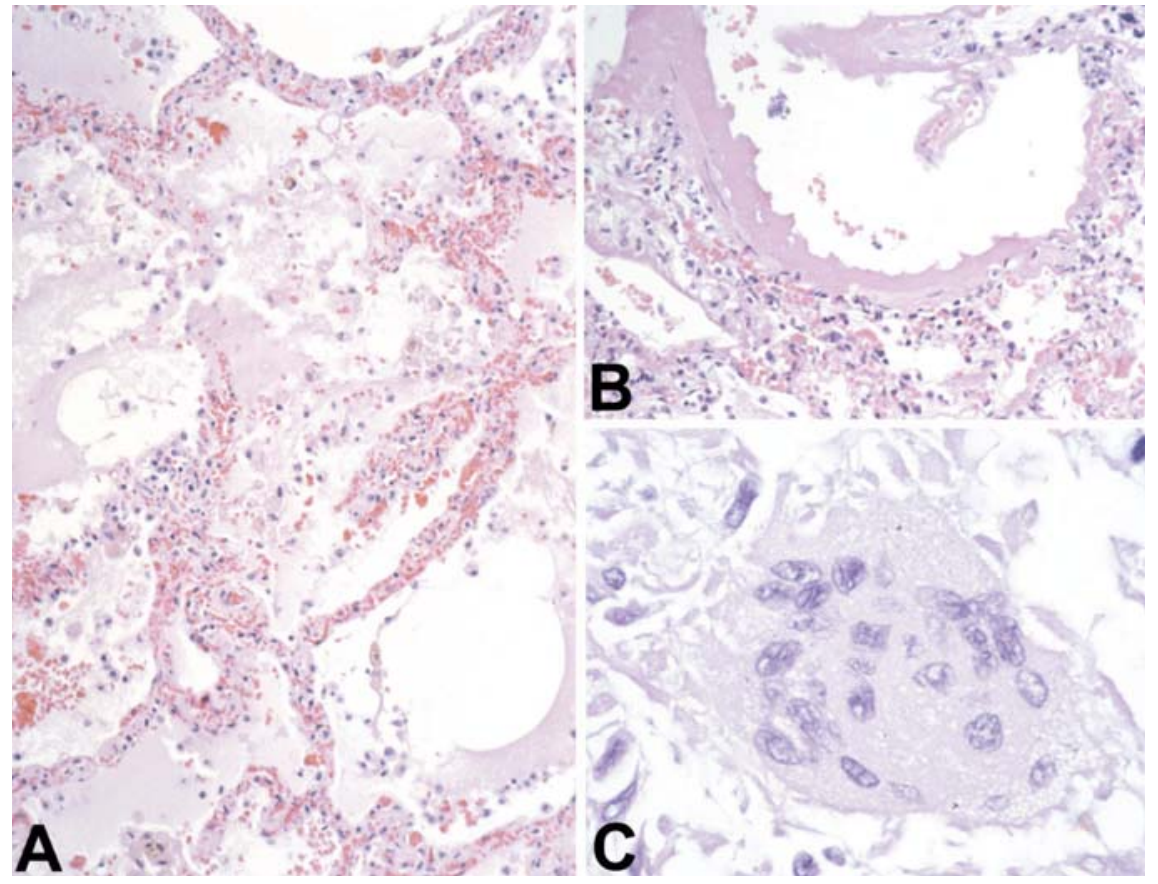

Figure 1. Histopathology of SARS in fatal human cases. (A) Low-power photomicrograph of lung showing interstitial pneumonia and intra-alveolar edema. (B) Higher power photomicrograph showing diffuse alveolar damage with prominent hyaline membranes. (C) Multinucleated syncytial giant cells are seen in some cases of fatal SARS. Note absence of discernable viral inclusions. Original magnifications, A, 20x; B, 40x; C, 100x.

\section{Histopathology}

Several reports have described diffuse alveolar damage with various levels of progression and severity as the main histopathologic findings in SARS patients [6,12-17]. Lungs typically show changes in the proliferative phase of diffuse alveolar damage, with hyaline-membrane formation, desquamation of epithelial cells, fibrin deposit in the alveolar space, and hyperplasia of type 2 pneumocytes (Fig. 1A, B). Increased mononuclear infiltrate in the interstitium can be seen in some cases. Other findings identified in some patients included focal intra-alveolar hemorrhage, necrotic inflammatory debris in small airways, and organizing pneumonia. In addition, multinucleated syncytial cells were seen in the intra-alveolar spaces of some patients who died 14 days or more after onset of illness (Fig. 1C). These cells contained abundant vacuolated cytoplasm with cleaved and convoluted nuclei. No obvious intranuclear or intracytoplasmic viral inclusions were identified. 


\section{Virus isolation and morphogenesis}

Ultrastructural characteristics of SARS-CoV have been described in recent reports $[18,19]$. Maturation is similar to features previously described for other coronaviruses [20-22]. Virions form by alignment of the helical nucleocapsids along the membranes of the endoplasmic reticulum or Golgi complex and by budding into the lumina of the cisternae (Fig. $2 \mathrm{~A}$ ). These vesicles become filled with virions and progress to the cell surface for release of the virus particles; large numbers of particles remain adherent to the plasma membrane at the cell surface (Fig. 2B). Other cytoplasmic structures associated with infection include double-membrane vesicles, which are the proposed replication complex for the virus [23, 24], and nucleocapsid inclusions (Fig. 2C). Immunogold electron microscopy, using a hyperimmune mouse ascitic fluid, was used to confirm the viral nature of the particles and inclusions (Fig. 2D). Infection of Vero E6 cells with SARS-CoV produces characteristic syncytial cells similar to those sometimes observed in lungs of patients who died. By light microscopy, abundant viral antigens can be detected in the cytoplasm of these cells grown in tissue culture (Fig. 2E).

\section{Tissue distribution and cellular targets}

In situ hybridization (ISH) and immunohistochemical (IHC) studies of tissues from SARS patients demonstrated coronavirus infection of upper airway bronchiolar epithelium [12, 25-27]. Infected ciliated columnar epithelial cells can be seen focally in lining epithelium of trachea and larger bronchi (Fig. 3A). Many of these infected cells slough off the epithelium and can be observed by using ISH within the bronchial lumen (Fig. 3B). Similarly, ultrastructural examination of bronchiolar lavage from a SARS patient showed numerous coronavirus-infected cells (Fig. 3C).

Abundant viral antigens can also be found distributed focally in parenchyma of lungs of some patients and are seen predominantly in cytoplasm of pneumocytes (Fig. 4A), in occasional macrophages (Fig. 4B) and in association with intra-alveolar necrotic debris and fibrin (Fig. 4C). Double-stain studies revealed that most SARS-CoV-infected cells are type 2 pneumocytes (co-labeled with surfactant), with occasional macrophages (co-labeled with CD68). Double-stain studies also detected viral nucleic acids with a distribution similar to that seen in IHC studies, mainly in pneumocytes and some macrophages [26]. Electron microscopic examination of lung tissues selected from areas with abundant IHC staining showed numerous coronavirus particles and nucleocapsid inclusions (Fig. 4D-F). Virions were seen in cytoplasmic vesicles and along the cell membranes of pneumocytes, in phagosomes of macrophages, and associated with fibrin in alveolar spaces. Because coronavirus particles may be confused morpho- 

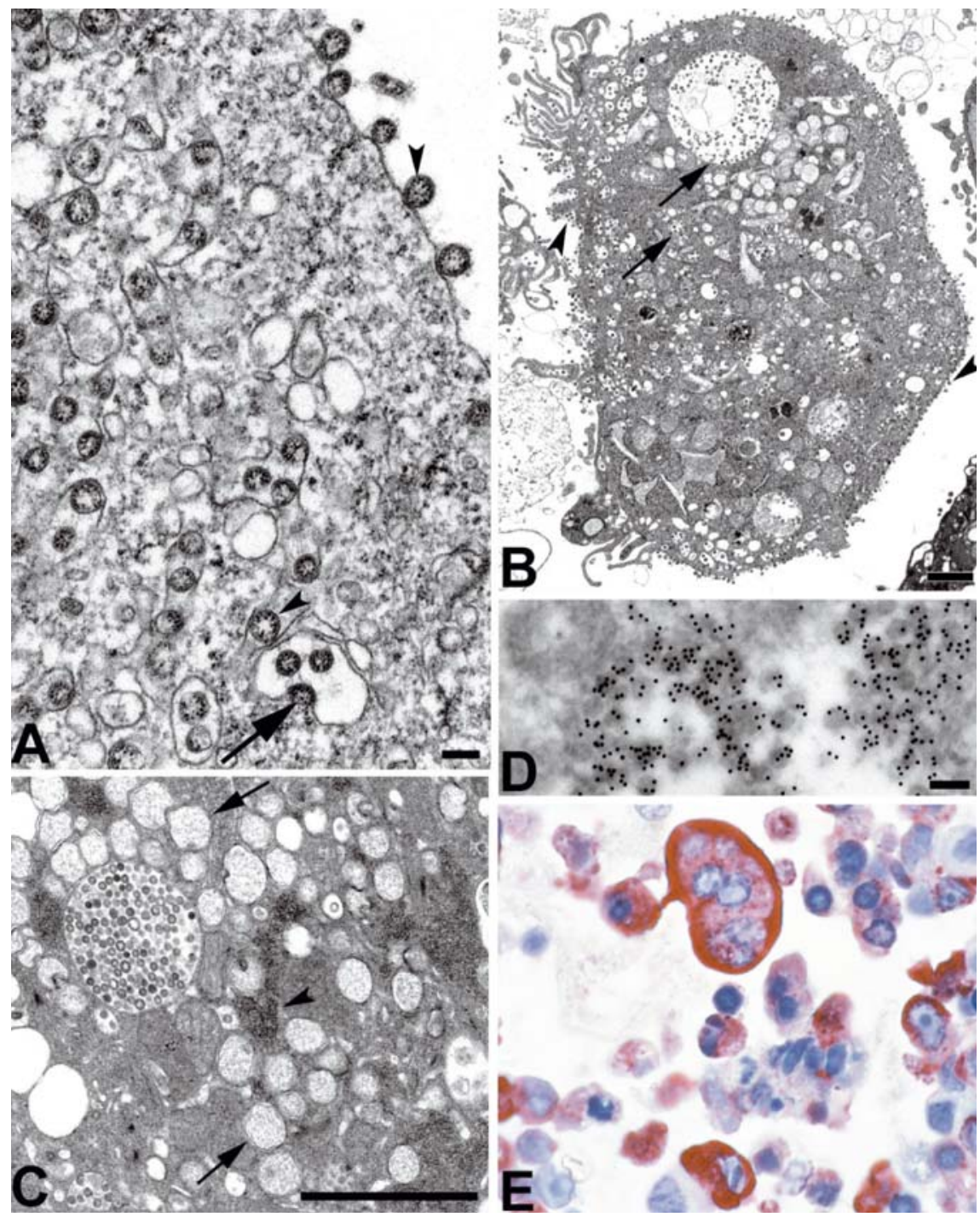

Figure 2. SARS-CoV-infected Vero E6 cells. (A) Virus particles form upon cytoplasmic membranes (arrow) and accumulate in vesicles as they progress to the cell surface. Cross-sections of the viral nucleocapsids (arrowheads) are evident in the virions. More virus particles are seen attached at the plasma membrane. (B) Low-magnification electron micrograph shows virus particles adherent to the plasma membrane (arrowheads) and within small and large vesicles (arrows) in the cytoplasm. (C) Cytoplasm of infected cell containing double-membrane vesicles (arrows), nucleocapsid inclusions (arrowhead), and virus particles within membranebound vesicles. (D) Immunogold labeling of intracellular virions. (Mouse hyperimmune ascitic fluid; goat anti-mouse conjugated to $12 \mathrm{~nm}$ gold.) (E) Immunohistochemical detection of SARS-CoV antigens in infected Vero E6 cells, using mouse anti-coronavirus. (Immunoalkaline phosphatase with napthol fast red substrate and hematoxylin counterstain.) Bars, A, B, C, $1 \mu \mathrm{m} ; \mathrm{D}, 100 \mathrm{~nm}$. Original magnification, E, 100x. 


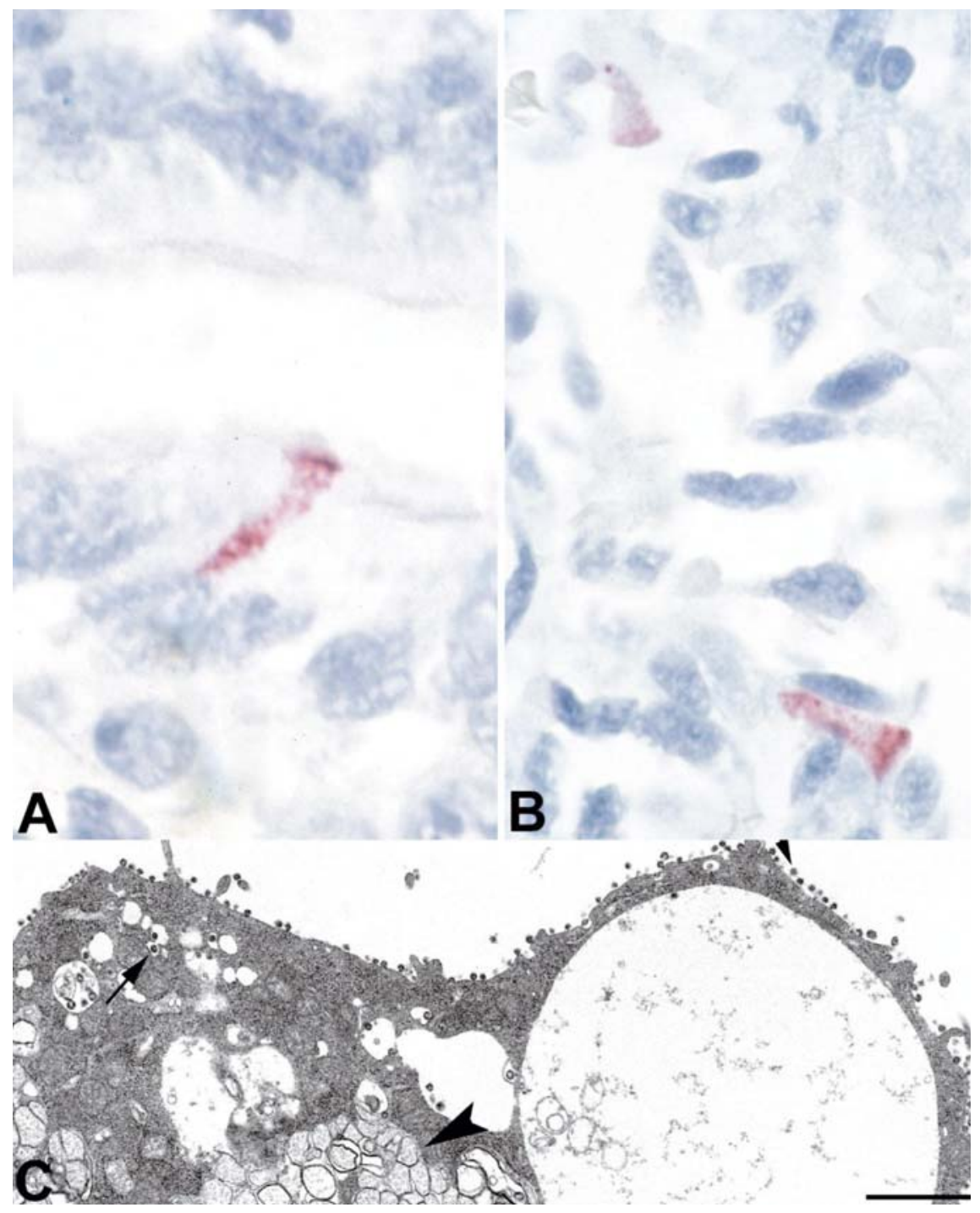

Figure 3. Cellular targets of infection in upper airways. (A) ISH of surface epithelium from a fatal human case. (B) ISH of infected cells that sloughed off into the lumen of a large bronchus. (C) Infected cells, presumed to be sloughed-off pneumocytes, are seen in a bronchial alveolar lavage obtained early in infection. Virus particles (arrows) are found along the cell surface and within cytoplasmic vesicles. Double-membrane vesicles (arrowhead) are also present. Original magnifications, A, B, 100x. Bar, C, $1 \mu \mathrm{m}$.

logically with other non-viral cellular components, definitive ultrastructural identification can be achieved by using immunogold labeling electron microscopy (IEM) (Fig. 4G). 


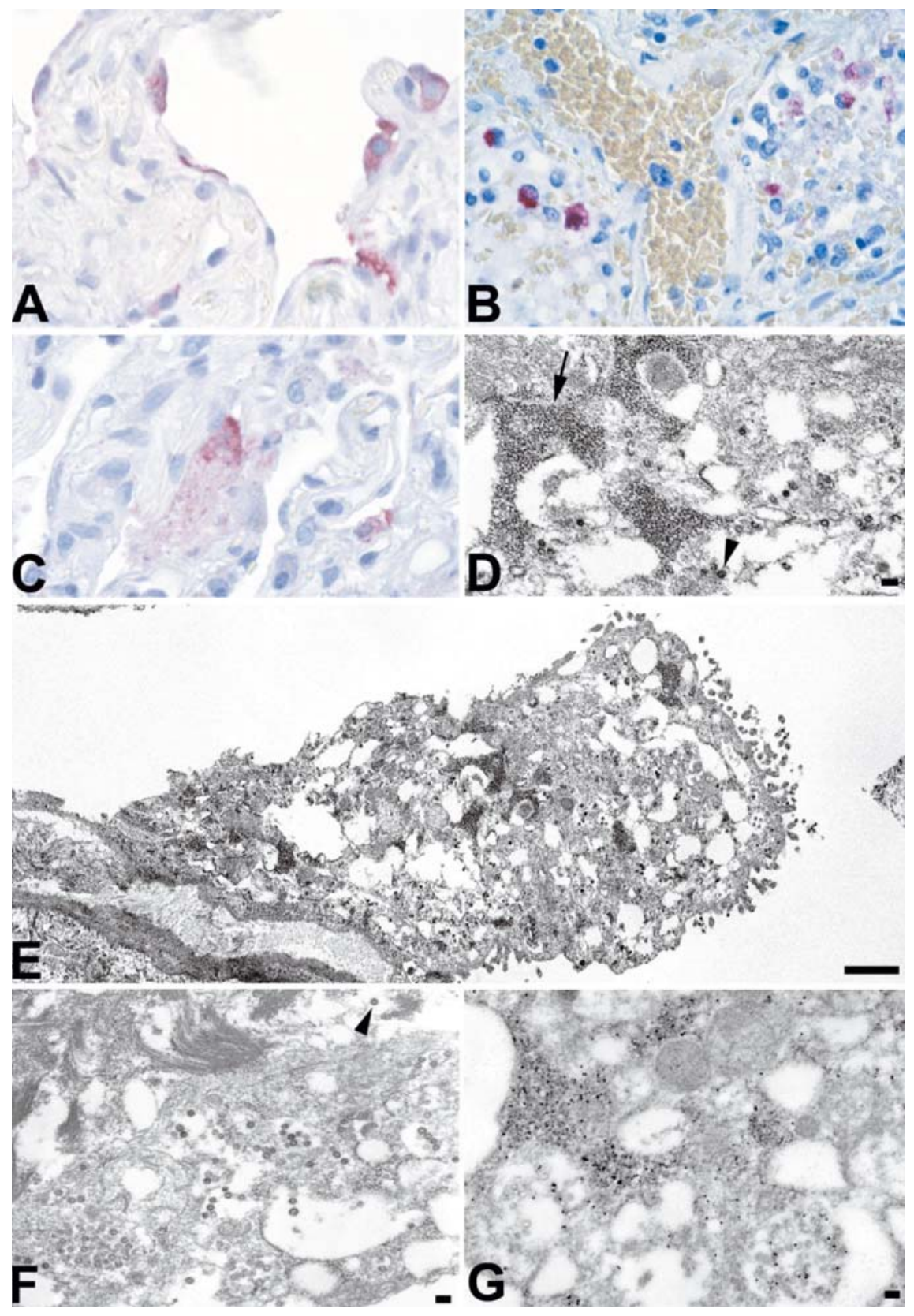

Figure 4. Cellular targets of infection in lower airways. (A) Type 2 pneumocytes containing viral antigens by IHC. (B) Intra-alveolar macrophages containing viral antigens as seen by IHC. (C) Antigen associated with intra-alveolar fibrin as seen by IHC. (D) High magnification of cell in figure (E), showing nucleocapsid inclusions (arrows) and virus particles (arrowhead). (E) Infected pneumocyte, attached at one edge to the basement membrane. (F) Virus particles 


\section{Pathogenesis and animal models}

The primary histopathologic lesions seen in the lungs of patients who died from SARS are somewhat nonspecific and can also be seen in acute lung injury cases that can be caused by infectious agents, trauma, drugs, or toxic chemicals [28]. Multinucleated syncytial cells similar to those seen in some SARS patients can also be found in a number of virus infections, including measles, parainfluenzaviruses, respiratory syncytial virus, and Nipah virus infections [28-30]. In an early study of four human SARS patients [6], we were not able to demonstrate viral antigens in the lung by IHC. The most likely explanation is that all tissue samples in the study were from patients with a clinical course averaging more than 2 weeks. For many virus infections, viral antigens and nucleic acids are cleared within 2 weeks of disease onset by the host immune response. It is also possible that the pulmonary damage associated with SARS is not caused directly by the virus but represents a secondary effect of cytokines or other factors induced by the virus infection. In influenza virus infections, viral antigens are seen predominantly in respiratory epithelial cells of large airways and are only rarely identified in pulmonary parenchyma despite concomitant and occasionally severe interstitial pneumonitis [31]. In recent reports by Shieh et al. [32] and Chong et al. [12], the temporal relationship between the duration of illness and clearance of SARS-CoV in human lung tissue was examined. Viral antigens and nucleic acids were detected only in pulmonary tissues of patients who died early in the disease. The development of specific IHC, ISH, and IEM assays to identify SARS-CoV in formalin-fixed, paraffin-embedded samples also allowed for the assessment of the cellular tropism of SARS$\mathrm{CoV}$ infection in human lung tissues. Localization of SARS-CoV in the lung occurs mainly in the cytoplasm of pneumocytes, primarily type 2 , and occasionally in alveolar macrophages. Type 2 pneumocytes are known to secrete pulmonary surfactant, resulting in reduced surface tension and preservation of the integrity of the alveolar space. These cells also play an important role in tissue restitution following lung damage. Moreover, there is mounting evidence to support their contribution to the development of acute inflammatory lung injury following exposure to biological or chemical agents. Additional studies are needed to further define the role of type 2 pneumocytes and alveolar macrophages in SARS-CoV infection.

The severe morbidity and mortality associated with SARS make it imperative that effective means to prevent and treat the disease be devel-

(arrowhead) among fibrin fibers adjacent to an infected pneumocyte. (G) Immunogold labeling confirms the viral nature of the nucleocapsid inclusions and the particles in membranebound vesicles. Original magnifications, A, B, C, 63×; Bars, D, F, G, $100 \mathrm{~nm}$; E, 1 m. (A, B, and $\mathrm{C}$ : immunoalkaline phosphatase with napthol fast red substrate and hematoxylin counterstain; G: mouse hyperimmune ascitic fluid and goat anti-mouse conjugated to $12 \mathrm{~nm}$ gold.) 
oped and evaluated, especially since it is not known whether the virus will reappear and exhibit a seasonal pattern of circulation like other respiratory virus pathogens or whether it will be independently reintroduced into the human population. Cynomolgus macaques have been reported to develop pathologic findings of pneumonia and have been proposed as an animal model for SARS [11]. Haagmans et al. [33] showed extensive SARS$\mathrm{CoV}$ antigen expression in experimentally infected cynomolgus macaques 4 days after infection. The antigens were mainly in alveolar lining epithelial cells with morphologic characteristics of type 1 pneumocytes, indicating type 1 pneumocytes are the primary target for SARS-CoV infection early in the disease. Type 1 pneumocytes normally represent $90 \%$ of the alveolar epithelial cell volume and are easily damaged during pulmonary infections or other types of injury. In a recent study on non-human primates [34], evidence was found of infection of mainly type 1 pneumocytes in addition to some type 2 pneumocytes and macrophages.

Small animal models, such as rodents, would be very useful for evaluating vaccines, immunotherapies, and antiviral drugs, and recently the mouse has been identified as an animal model for this purpose [35]. In those studies, microscopic examination of trachea, bronchus, lung, thymus, and heart on day 2 after infection revealed mild and focal peribronchiolar mononuclear inflammatory infiltrates (Fig. 5A) with no significant histopathologic change in other organs. Viral antigens and nucleic acids were focally distributed in bronchiolar epithelial cells (Fig. 5B), and virions were found in these same areas by ultrastructural analysis (Fig. 5C, D). Data indicate that SARS-CoV replicates to high enough titer in mice that we will be able to evaluate vaccines and antivirals in this model. The mouse and other small animal models [36] might also be used to test the ability of the virus to replicate and cause disease and, thus, facilitate identification of host-immune mechanisms that contribute to the resolution of SARS-CoV infection.

\section{Conclusions}

The emergence of SARS-CoV has posed a major threat to global health. A specific etiologic diagnosis is particularly important during such outbreaks because of the impact on hospital infection control and other public health measures. The discovery of this new virus occurred through a broad-based and multidisciplinary effort by clinical, epidemiologic, and laboratory investigators and speaks to the power of a global collaborative effort to address the ever-present threat of emerging infectious diseases. The identification of this novel coronavirus relied on classic tissue-culture isolation to amplify the pathogen, on electron-microscopic studies to identify the type of virus, and on molecular studies to confirm the identity of the virus, characterize its unique nature, and help link it to the disease. The discovery of this previously unknown virus, a member of the family 


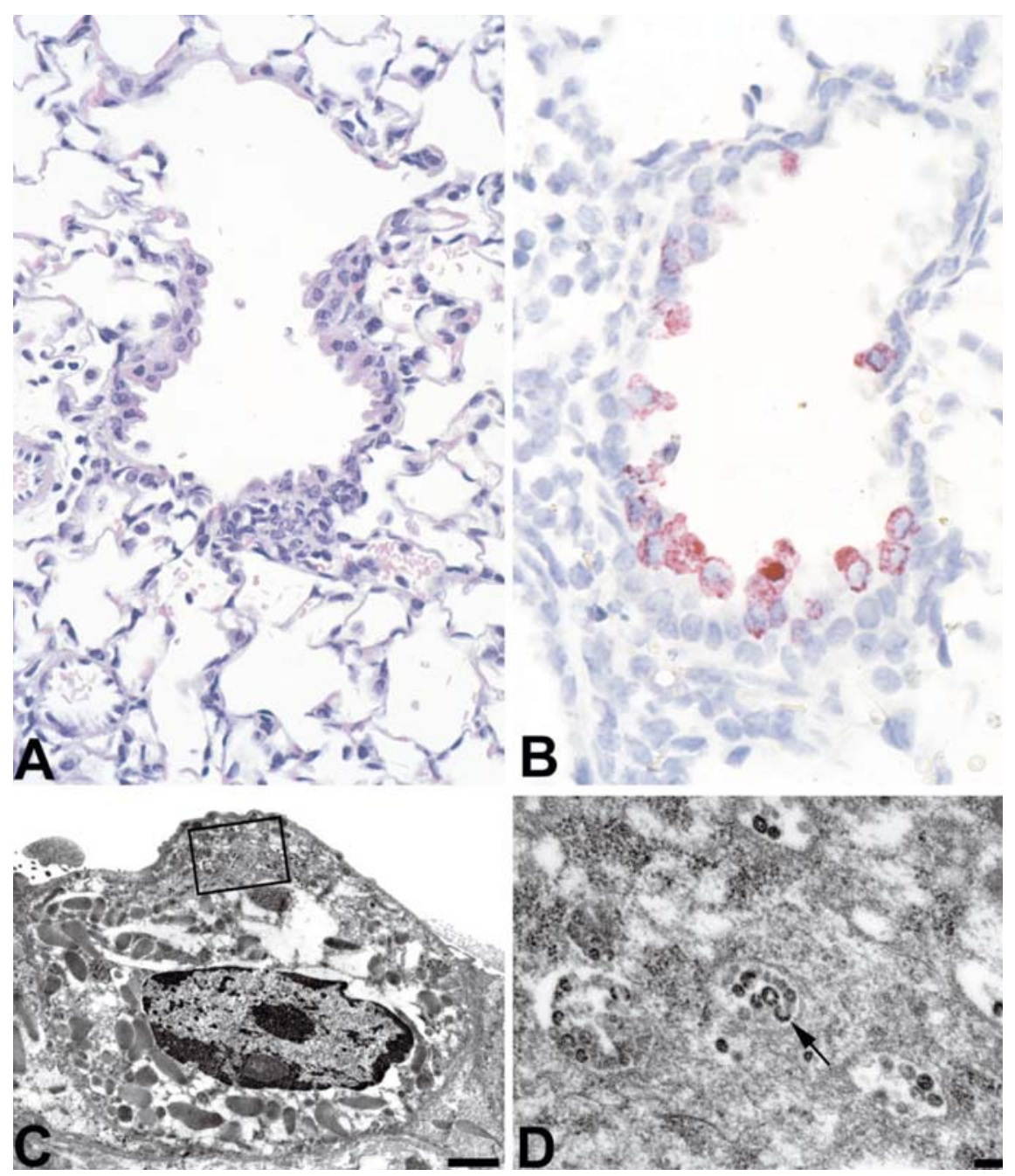

Figure 5. Mouse animal model of SARS. (A) Hematoxylin and eosin-stained tissue showing mild inflammation in peribronchiolar areas. (B) Viral antigens in bronchial epithelial cells as seen by using IHC. (Immunoalkaline phosphatase with napthol fast red substrate and hematoxylin counterstain.) (C) Virus as seen in bronchial epithelial cells by electron microscopy. (D) Higher magnification of boxed area in $\mathrm{C}$, showing numerous spherical particles (arrow) in cytoplasmic vesicles. Original magnifications, A, 20x; B, 63×. Bars, C, $1 \mu \mathrm{m} ; \mathrm{D}, 100 \mathrm{~nm}$.

Coronaviridae, underscores the importance of versatile laboratory techniques, such as virus isolation and electron microscopy, in identifying etiologic pathogens. As with previous outbreak investigations, electron microscopy proved to be a rapid technique that did not require specific reagents nor prior knowledge of a particular agent but that could never- 
theless categorize a pathogen on the basis of its appearance and morphogenesis. This technique was combined with other traditional methods, including virus isolation in suckling mice and cell culture, histopathologic examination, and serologic analysis. Molecular techniques of polymerase chain reaction (PCR), reverse-transcription PCR, and real-time PCR were also used and were invaluable for the characterization and discovery of this novel virus.

In summary, since the clinical features of SARS-CoV infection can be similar to those of many other respiratory infections, a definitive diagnosis can only be made by laboratory confirmation. Traditional pathologic methods in association with more contemporary molecular pathologic methods should help enhance the pathologic diagnosis and further our understanding of the pathogenesis of SARS-CoV infection.

\section{Acknowledgements}

The authors thank Wun-Ju Shieh, Chris Paddock, and Jeannette Guarner for pathologic evaluation; Kathleen Tatti for in situ hybridization studies; Tom Ksiazek for virus isolates; Pierre Rollin for antibodies; Kanta Subbarao for animal model collaborations; and Claudia Chesley for editorial assistance.

\section{References}

1 Anonymous (2003) Acute respiratory syndrome. China, Hong Kong Special Administrative Region of China, and Viet Nam. Wkly Epidemiol Rec 78: 73-74

2 Anonymous (2003) WHO issues consensus document on the epidemiology of SARS. Wkly Epidemiol Rec 78: 373-375

3 Anonymous (2003) Outbreak of severe acute respiratory syndrome--worldwide, 2003. MMWR Morb Mortal Wkly Rep 52: 226-228

4 Anonymous (2003) Update: severe acute respiratory syndrome - worldwide and United States, 2003. MMWR Morb Mortal Wkly Rep 52: 664-665

5 Anonymous (2003) Update: Outbreak of severe acute respiratory syndrome worldwide, 2003. MMWR Morb Mortal Wkly Rep 52: 241-6, 248

6 Ksiazek TG, Erdman D, Goldsmith CS, Zaki SR, Peret T, Emery S, Tong S, Urbani C, Comer JA, Lim W et al (2003) A novel coronavirus associated with severe acute respiratory syndrome. N Engl J Med 348: 1953-1966

7 Peiris JS, Lai ST, Poon LL, Guan Y, Yam LY, Lim W, Nicholls J, Yee WK, Yan WW, Cheung MT et al (2003) Coronavirus as a possible cause of severe acute respiratory syndrome. Lancet 361: 1319-1325

8 Drosten C, Gunther S, Preiser W, van der WS, Brodt HR, Becker S, Rabenau H, Panning M, Kolesnikova L, Fouchier RA et al (2003) Identification of a 
novel coronavirus in patients with severe acute respiratory syndrome. $N$ Engl J Med 348: 1967-1976

9 Marra MA, Jones SJ, Astell CR, Holt RA, Brooks-Wilson A, Butterfield YS, Khattra J, Asano JK, Barber SA, Chan SY et al (2003) The genome sequence of the SARS-associated coronavirus. Science 300: 1399-1404

10 Rota PA, Oberste MS, Monroe SS, Nix WA, Campagnoli R, Icenogle JP, Penaranda S, Bankamp B, Maher K, Chen MH et al (2003) Characterization of a novel coronavirus associated with severe acute respiratory syndrome. Science 300: 1394-1399

11 Kuiken T, Fouchier RA, Schutten M, Rimmelzwaan GF, van Amerongen G, van Riel D, Laman JD, de Jong T, van Doornum G, Lim W et al (2003) Newly discovered coronavirus as the primary cause of severe acute respiratory syndrome. Lancet 362: 263-270

12 Chong PY, Chui P, Ling AE, Franks TJ, Tai DY, Leo YS, Kaw GJ, Wansaicheong G, Chan KP, Ean Oon LL et al (2004) Analysis of deaths during the severe acute respiratory syndrome (SARS) epidemic in Singapore: challenges in determining a SARS diagnosis. Arch Pathol Lab Med 128: 195-204

13 Ding Y, Wang H, Shen H, Li Z, Geng J, Han H, Cai J, Li X, Kang W, Weng D et al (2003) The clinical pathology of severe acute respiratory syndrome (SARS): a report from China. J Pathol 200: 282-289

14 Franks TJ, Chong PY, Chui P, Galvin JR, Lourens RM, Reid AH, Selbs E, McEvoy CP, Hayden CD, Fukuoka J et al (2003) Lung pathology of severe acute respiratory syndrome (SARS): a study of 8 autopsy cases from Singapore. Hum Pathol 34: 743-748

15 Lang ZW, Zhang LJ, Zhang SJ, Meng X, Li JQ, Song CZ, Sun L, Zhou YS, Dwyer DE (2003) A clinicopathological study of three cases of severe acute respiratory syndrome (SARS). Pathology 35: 526-531

16 Leung WK, To KF, Chan PKS, Chan HLY, Wu AKL, Lee N, Yuen KY, Sung JJY (2003) Enteric involvement of Severe Acute Respiratory Syndrome-associated coronavirus infection. Gastroenterology 125: 1011-1017

17 Nicholls JM, Poon LL, Lee KC, Ng WF, Lai ST, Leung CY, Chu CM, Hui PK, Mak KL, Lim W et al (2003) Lung pathology of fatal severe acute respiratory syndrome. Lancet 361: 1773-1778

18 Goldsmith CS, Tatti KM, Ksiazek TG, Rollin PE, Comer JA, Lee WW, Rota PA, Bankamp B, Bellini WJ, Zaki SR (2004) Ultrastructural characterization of SARS coronavirus. Emerg Infect Dis 10: 320-326

19 Ng ML, Tan SH, See EE, Ooi EE, Ling AE (2003) Proliferative growth of SARS coronavirus in Vero E6 cells. J Gen Virol 84: 3291-3303

20 Becker WB, McIntosh K, Dees JH, Chanock RM (1967) Morphogenesis of avian infectious bronchitis virus and a related human virus (strain 229E). $J$ Virol 1: 1019-1027

21 Dubois-Dalcq M, Holmes KV, Rentier B (1984) Assembly of Coronaviradae, in: Assembly of Enveloped RNA Viruses, Springer-Verlag, Wien, 100-119

22 Oshiro LS, Schieble JH, Lennette EH (1971) Electron microscopic studies of coronavirus. J Gen Virol 12: 161-168 
23 Pedersen KW, van der Meer Y, Roos N, Snijder EJ (1999) Open reading frame 1a-encoded subunits of the arterivirus replicase induce endoplasmic reticulumderived double-membrane vesicles which carry the viral replication complex. $J$ Virol 73: 2016-2026

24 Gosert R, Kanjanahaluethai A, Egger D, Bienz K, Baker SC (2002) RNA replication of mouse hepatitis virus takes place at double-membrane vesicles. $J$ Virol 76: 3697-3708

25 Nakajima N, Asahi-Ozaki Y, Nagata N, Sato Y, Dizon F, Paladin FJ, Olveda RM, Odagiri T, Tashio M, Sata T (2003) SARS coronavirus-infected cells in lung detected by new in situ hybridization technique. Jpn J Infect Dis 56: 139-141

26 Shieh WJ, Huang S, Paddock CD, Guarner J, Muller S, Goldsmith CS, Tatti K, Packard M, Subbarao K, Zaki SR. Immunohistochemical, in situ hybridization, and ultrastructural localization of SARS-associated coronavirus in a fatal case of severe acute respiratory syndrome in Taiwan. Hum Pathol; in press

27 To KF, Tong JH, Chan PK, Au FW, Chim SS, Chan KC, Cheung JL, Liu EY, Tse GM, Lo AW et al (2004) Tissue and cellular tropism of the coronavirus associated with severe acute respiratory syndrome: an in-situ hybridization study of fatal cases. J Pathol 202: 157-163

28 Anonymous (1997) Acute lung injury patterns: Diffuse alveolar damage and bronchiolitis obliterans-organizing pneumonia. In: AA Katzenstein (ed): Katzenstein and Askin's Surgical Pathology of Non-Neoplastic Lung Disease, 3rd ed., WB Saunders, Philadelphia, 14-47

29 Zaki SR, Bellini WJ (1997) Measles, in: Connor DH, Chandler FW, Schwartz DA, Manz HJ, Lack EE (eds): Pathology of Infectious Diseases, Appleton and Lange, Stamford, CT, 233-244

30 Wong KT, Shieh WJ, Kumar S, Norain K, Abdullah W, Guarner J, Goldsmith CS, Chua KB, Lam SK, Tan CT et al (2002) Nipah virus infection: pathology and pathogenesis of an emerging paramyxoviral zoonosis. Am J Pathol 161: 2153-2167

31 Guarner J, Shieh WJ, Dawson J, Subbarao K, Shaw M, Ferebee T, Morken T, Nolte KB, Freifeld A, Cox N, Zaki SR (2000) Immunohistochemical and in situ hybridization studies of influenza A virus infection in human lungs. Am J Clin Pathol 114: 227-233

32 Shieh WJ, Guarner J, Paddock C, Greer P, Tatti K, Fischer M, Layton M, Philips M, Bresnitz E, Quinn CP et al (2003) The critical role of pathology in the investigation of bioterrorism-related cutaneous anthrax. Am J Pathol 163: 19011910

33 Haagmans BL, Kuiken T, Martina BE, Fouchier RA, Rimmelzwaan GF, van Amerongen G, van Riel D, de Jong T, Itamura S, Chan KH et al (2004) Pegylated interferon-alpha protects type 1 pneumocytes against SARS coronavirus infection in macaques. Nat Med 10: 290-293

34 McAuliffe J, Vogel L, Roberts A, Fahle G, Fischer S, Shieh WJ, Butler E, Zaki S, St.Claire M, Murphy B, Subbarao K (2004) Replication of SARS coron- 
avirus administered into the respiratory tract of African Green, rhesus and cynomolgus monkeys. J Virol 330: 8-15

35 Subbarao K, McAuliffe J, Vogel L, Fahle G, Fischer S, Tatti K, Packard M, Shieh WJ, Zaki S, Murphy B (2004) Prior infection and passive transfer of neutralizing antibody prevent replication of severe acute respiratory syndrome coronavirus in the respiratory tract of mice. $J$ Virol 78: 3572-3577

36 Roberts A, Vogel L, Guarner J, Hayes N, Murphy B, Zaki S, Subbarao K. SARS coronavirus infection of golden Syrian hamsters. $J$ Virol; in press 